INFO ARTIKEL

Riwayat Artikel:

Diterima : 10 Juli 2020

Disetujui : 9 Agustus 2020

\title{
PENDIDIKAN
}

\section{BELAJAR GEOGRAFI DENGAN MEDIA KOMIK SERTA PENGARUHNYA TERHADAP MINAT BELAJAR SISWA}

\author{
Nur Aziza ${ }^{1}$, Laili Rosita ${ }^{2}$ \\ ${ }^{1,2}$ Pendidikan Geografi, Fakultas Keguruan dan Ilmu Pendidikan, Universitas PGRI Palembang \\ (छ)*rositalaili09@gmail.com
}

\begin{abstract}
One of the problem is the lack of students interest in participating on geography learning, either of can be seen from the number of students who are passive when taking lessons aside from that comic media has never been used before. Therefore this research was conducted with a quasi-experimental method which aims to find out whether implementing learning using comic media can influence the interest in learning geography students of class X at SMA Karya Ibu Palembang in Academic Year 2018/2019. The population of this research was all students in class X IPS of SMA Karya Ibu Palembang with 60 students Sampling method taken with saturation sampling technique so obtained class X IPS 1 as an experimental class with a total of 30 students and X IPS 2 as a control class with 30 students. Data collection techniques using a questionnaire then tested the hypothesis by the t-test.

Based on the analysis of learning interest data through the $t$-test, the t-value $=14.1$ is obtained while the $t$-table $=1.6732$. From the calculation results, it is obtained that $t$-count $\geq t$-table, Ha is accepted with the average value of the interest test of the experimental class 117.7 and the control class 105.7. Thus it can be concluded that there is an influence of the use comic media on the students interest in learning geography of class X at SMA Karya Ibu Palembang.
\end{abstract}

Keywords: Learning Interest, Comic Media

\begin{abstract}
ABSTRAK
Dilatarbelakangi kurangnya minat siswa dalam mengikuti pembelajaran geografi salah satunya bisa dilihat dari banyaknya siswa yang pasif saat mengikuti pelajaran selain itu media komik belum pernah digunakan sebelumnya. Oleh karena itu dilakukan penelitian dengan metode quasi eksperimen ini yang bertujuan untuk mengetahui apakah dengan menerapkan pembelajaran menggunakan media komik dapat mempengaruhi minat belajar geografi siswa kelas X di SMA Karya Ibu Palembang Tahun Ajaran 2018/2019. Populasi penelitian ini adalah seluruh siswa kelas X IPS SMA Karya Ibu Palembang yang berjumlah seluruhnya 60 siswa dengan pengambilan sampel yaitu teknik sampling jenuh dengan kelas $\mathrm{X}$ IPS 1 sebagai kelas eksperimen dengan jumlah 30 siswa dan X IPS 2 sebagai kelas kontrol dengan jumlah 30 siswa. Teknik pengumpulan data menggunakan angket yang selanjutnya diuji hipotesisnya dengan rumus uji-t.

Berdasarkan analisis data minat belajar melalui uji-t maka diperoleh nilai $t_{\text {hitung }}=14,1$ sedangkan $t_{\text {tabel }}=$ 1,6732. Dari hasil perhitungan didapat bahwa $t_{\text {hitung }} \geq t_{\text {tabel }}$ maka Ha diterima dengan nilai rata-rata tes minat belajar kelas eksperimen117,7 dan kelas kontrol 105,7. Dengan demikian dapat disimpulkan bahwa terdapat pengaruh penggunaan media komik terhadap minat belajar geografi siswa kelas X di SMA Karya Ibu Palembang Tahun Ajaran 2018/2019".
\end{abstract}

Kata kunci: Minat Belajar, Media Komik 


\section{PENDAHULUAN}

Oktavianto (2019), menyatakan bahwa, geografi merupakan serangkaian pengetahuan guna menjelaskan berbagai fenomena alam yang pernah terjadi, sedang terjadi, dan akan terjadi di muka bumi dikaitkan dengan kehidupan manusia. Sebagai sebuah ilmu, geografi memerlukan teori. Hal ini penting karena penemuan di bidang geografi selalu didahului teori. Geografi sebagai sebuah ilmu dipastikan dapat dipelajari dan diajarkan. Belajar dan mengajar geografi dapat dilakukan melalui pendidikan geografi, baik secara formal maupun non formal. Maryani (2011), menyarankan agar pembelajaran geografi berorientasi pada: 1) fenomena yang terjadi dan berkembang di sekitar peserta didik; 2) dicocokkan dengan kepentingan dan kondisi psikis perkembangan siswa; 3) peningkatan kualitas hidup melalui dengan mengenalkan sumber daya serta pemanfaatan; 4) harus memperhatikan keberlangsungan di masa yang akan datang; dan 5) memberikan pemahaman menyeluruh, baik dalam bentuk peluang maupun tantangan. Berhasil dan tidaknya kegiatan pembelajaran geografi ditentukan oleh beberapa faktor, diantaranya faktor pengajar/guru, buku, dan siswa (Bintarto, 1988).

Sampai saat ini, masalah yang sering terjadi dalam proses pembelajaran geografi adalah masih kurang keinginan dan motivasi atau semangat siswa dalam pembelajaran geografi. Minat berkaitan dengan rasa senang atau tidak senang terhadap sesuatu. Oleh karena itu minat sangat dibutuhkan apabila hendak melakukan sesuatu seperti belajar. Minat menentukan aktivitas dan perilaku yang menyebabkan seseorang aktif dalam suatu kegiatan atau kondisi, atau dengan kata lain minat dapat menjadi sebab atau faktor motivasi dari suatu kegiatan (Darmadi, 2017). Salah satu alasan minat dalam pembelajaran geografi masih terlihat rendah adalah pelajaran geografi seringkali dianggap pelajaran yang susah dipahami, tidak menarik, dan membosankan. Sehingga seringkali juga tujuan pembelajaran geografi tidak tercapai. Beberapa kekurangan dalam pembelajaran disebabkan karena masih terdapat kekurangan pada kegiatan pembelajaran di kelas. Salah satu penyebabnya adalah kurangnya penggunaan media pembelajaran. Media adalah segala sesuatu yang dapat digunakan untuk menyalurkan pesan dari pengirim ke penerima sehingga dapat merangsang pikiran, perasaan dan minat serta perhatian siswa yang sedemikian rupa sehinga proses belajar terjadi (Sadiman dkk, 2014).

Media adalah salah satu hal yang sangat penting dan diperlukan dalam kegiatan pembelajaran karena media mempunyai kelebihan dapat meningkatkan aktivitas dalam kegiatan pembelajaran yang akan berpengaruh terhadap hasil belajar siswa, dikarenakan siswa akan lebih tertarik dan termotivasi mengikuti kegiatan pembelajaran. Dengan adanya media sebagai saluran dalam penyampaian pesan diharapkan timbulnya minat belajar sehingga membantu keefektifan proses pembelajaran yang membawa pengaruh baik terhadap hasil belajar siswa. Karena salah satu faktor yang mempengaruhi keberhasilan proses belajar adalah adanya minat belajar. Berdasarkan hal tersebut dapat dikatakan bahwa media sangat diperlukan dalam pembelajaran terutama untuk meningkatkan minat belajar siswa di kelas tidak terkecuali dalam pembelajaran geografi.

Salah satu media visual yang digunakan dalam penelitian ini adalah media komik. Komik adalah kumpulan visual atau gambar dan symbolsimbol yang berurutan dan berdekatan/ bersebelahan yang disesuaikan dengan hal yang ingin disampaikan dengan tujuan untuk memberikan informasi atau untuk mencapai tanggapan estetis dari para pembaca (McCloud, 2002). Komik merupakan sebuah karya yang sangat populer dan memiliki banyak penggemar terutama kalangan usia muda. Oleh karena keuntungan inilah menjadi salah satu inspirasi bahwa belajar geografi tidak harus selalu bersumber dari buku, tapi bisa menggunakan media komik ini yang tentu saja sangat menarik dan membuat siswa semangat mengikuti pelajaran. Bila komik identik berasal dari Jepang, tapi saat ini sudah banyak komik karya anak 
negeri yang bisa guru manfaatkan sebagai media pembelajaran yang efektif dan menyenangkan. Berdasarkan jenisnya, media komik tergolong dalam kelompok media visual, yaitu media yang hanya dapat ditangkap dengan indra penglihatan saja, tidak memiliki atau tidak mampu mengeluarkan suara. Contohnya adalah slide, foto, lukisan, gambar, dan berbagai bentuk bahan yang dicetak (Sumiharsono dkk, 2017).

Media komik merupakan salah satu media yang sesuai untuk dimanfaatkan dalam pembelajaran geografi khususnya pada siklus terjadinya air (siklus hidrologi). Kelebihan komik sebagai media pembelajaran menurut Trimo (dalam Lestari dkk, 2009), yaitu menambah penguasaan verbal berupa kata-kata bagi pembacanya dan mempermudah anak didik menangkap dan memahami hal-hal atau rumusan yang bersifat bias. Karena fenomena-fenomena dalam pelajaran geografi bersifat abstrak sehingga materi yang disampaikan tidak bisa jika hanya dikhayalkan saja oleh siswa tanpa media bantu lainnya. Selain tu juga komik dapat meningkatkan minat baca seseorang karena dilengkapi dengan alur cerita serta gambar karakter yang unik dan menarik.

Berdasarkan beberapa kelebihan dari media komik tersebut, peneliti merasa perlu untuk membantu guru geografi di SMA Karya Ibu Palembang untuk menyediakan media pembelajaran komik sebagai alat bantu guna meningkatkan keberhasilan pembelajaran salah satunya adalah untuk meningkatkan minat belajar pada materi hidrosfer yang merupakan salah satu materi dalam pelajaran geografi yang membutuhkan media dalam penyampaian materinya adalah hidrosfer. Materi hidrosfer lebih banyak menjelaskan kegiatan fisik yang harusnya oleh siswa dilihat secara nyata misalnya terjadinya hujan, ada siklus yang tahap pertahap menjelaskan proses tersebut, sehingga membutuhkan perilaku nampak yang harus diberikan oleh guru. Materimateri tersebut jika hanya dikhayalkan akan tidak efektif dibandingkan dilihat secara jelas ataupun ada ilustrasi yang mewakili untuk bisa dipelajari. Maka dari itu guru memerlukan media dalam mendukung penyampaian materi tersebut. Disamping karena pembelajaran geografi di sekolah ini belum pernah menggunakan media komik sebelumnya. Hal tersebut sekaligus menjadi tujuan dari penelitian ini adalah untuk mengetahui pengaruh penggunaan media komik terhadap minat belajar geografi siswa kelas $\mathrm{X}$ di SMA Karya Ibu Palembang.

Media komik yang akan digunakan dalam penelitian ini merupakan hasil karya Arina Sholiha, seorang Mahasiswi Universitas Negeri Semarang yang diunduh secara gratis melalui blog pribadi milik penulis komik dengan alamat web http://arinacan.blogspot.com/2016/. Penelitian ini sejalan dengan hasil penelitian terdahulu oleh Larasati (2016) dengan judul " Penggunaan Media Komik Terhadap Minat, Motivasi dan Hasil Belajar Siswa Pada Mata Pelajaran IPS Geografi Kelas VII SMP N 7 Metro Tahun Pelajaran 2015/2016" dengan hasil penelitian bahwa ada pengaruh penggunaan media komik terhadap motivasi belajar siswa termasuk ke dalam kategori sedang.

\section{METODE PENELITIAN}

Metode yang digunakan dalam penelitian ini adalah metode eksperimen. Metode eksperimen yang digunakan dalam penelitian ini adalah quasi experimental design (eksperimen semu). Metode eksperimen semu (quasi eksperimen) pada dilakukan apabila penelitian eksperimen murni tidak dapat dipenuhi secara utuh, karena pengendalian variabel yang terkait subjek penelitian tidak dapat dilakukan sepenuhnya, sehingga penelitian harus dilakukan dengan menggunakan intack group. Jadi mesti menggunakan seluruh subjek dalam kelompok belajar untuk diberi perlakuan bukan menggunakan subjek yang diambil secara acak (Siyoto dan Sodik, 2015). Desain penelitian ini yaitu Posttest-Only Control Group Design.

Penelitian ini melibatkan dua variabel yaitu variabel bebas dan variabel terikat. Variabelvariabel tersebut dapat diuraikan sebagai berikut:

1. Variabel bebas $(\mathrm{X})$ dalam penelitian ini adalah media komik. 
2. Variabel terikat (Y) dalam penelitian ini adalah minat belajar

Populasi dalam penelitian ini adalah seluruh siswa kelas X IPS di SMA Karya Ibu Palembang Tahun Ajaran 2018/2019. Sementara pengambilan sampel yang digunakan dalam penelitian ini adalah Non Probability Sampling dengan menggunakan teknik sampel jenuh, yaitu teknik penentuan sampel bila semua anggota populasi digunakan sebagai sampel. Sampel dalam penelitian ini adalah siswa kelas X IPS 2 sebagai kelas eksperimen dan kelas X IPS 1 sebagai kelas kontrol.

Teknik yang digunakan untuk mengumpulkan data pada penelitian ini adalah jenis tes berupa angket dan dokumentasi. Adapun kriteria penilaian angket pengaruh media komik terhadap minat belajar siswa menggunakan skala Likert dengan 5 kriteria penilaian sebagai berikut:

Table 1. Kriteria Penilaian Angket

\begin{tabular}{|l|l|l|}
\hline Kategori & \multicolumn{1}{|c|}{ Keterangan } & Skor \\
\hline SL & Selalu & 5 \\
\hline SR & Sering & 4 \\
\hline K & Kadang-kadang & 3 \\
\hline HTP & Hampir tidak pernah & 2 \\
\hline TP & Tidak Pernah & 1 \\
\hline
\end{tabular}

Sumber : (Sugiyono, 2016:135)

Instrumen terlebih dahulu diuji coba sebelum diterapkan dalam penelitian, langkah selanjutnya setelah pengambilan data minat belajar dilakukan pada kelas kontrol dan kelas eksperimen langkah selanjutnya yang dilakukan adalah uji prasyarat berupa uji nornalitas dan homogenitas dan yang terakhir adalah analisis data penelitian berupa uji hipotesis menggunakan rumus uji $t$ dengan kriteria Ho : $\mu_{1}=\mu_{2}$ (tidak ada perbedaan minat belajar siswa antara kelas eksperimen dan kelas kontrol) dan Ho: $\mu_{1} \neq \mu_{2}$ (ada perbedaan minat belajar siswa antara kelas eksperimen dan kelas kontrol).
Jumlah pernyataan dalam angket adalah 39 butir dengan 3 indikator minat belajar yaitu perasaan senang, perhatian, dan ketertarikan yang kemudian dikembangkan menjadi 39 butir pernyataan. Kisi-kisi instrumen minat belajar sebagai berikut:

Tabel 2. Kisi-kisi Angket Minat Belajar

\begin{tabular}{|c|l|}
\hline $\begin{array}{c}\text { Indikator } \\
\text { Minat Belajar }\end{array}$ & \multicolumn{1}{|c|}{ Sub-Indikator } \\
\hline \multirow{5}{*}{$\begin{array}{c}\text { Perasaan } \\
\text { Senang }\end{array}$} & $\begin{array}{l}\text { Pendapat siswa tentang } \\
\text { pembelajaran geografi }\end{array}$ \\
\cline { 2 - 3 } Kesan siswa terhadap guru \\
geografi \\
\cline { 2 - 2 } & $\begin{array}{l}\text { Perasaan siswa selama mengikuti } \\
\text { pembelajaran geografi }\end{array}$ \\
\hline \multirow{5}{*}{ Perhatian } & $\begin{array}{l}\text { Perrhatian saat mengikuti } \\
\text { pembelajaran geografi }\end{array}$ \\
\cline { 2 - 2 } & $\begin{array}{l}\text { Perhatian siswa saat diskusi } \\
\text { pelajaran geografi }\end{array}$ \\
\cline { 2 - 2 } & $\begin{array}{l}\text { Menyelesaikan } \\
\text { pelajaran dengan baik dan tepat } \\
\text { Waktu }\end{array}$ \\
\hline \multirow{5}{*}{ Ketertarikan } & $\begin{array}{l}\text { Rasa ingin tahu siswa saat } \\
\text { mengikuti pembelajaran geografi }\end{array}$ \\
\cline { 2 - 2 } & $\begin{array}{l}\text { Penerimaan siswa saat diberi } \\
\text { tugas/RP oleh guru }\end{array}$ \\
\cline { 2 - 2 } & $\begin{array}{l}\text { Ketertarikan terhadap bahan } \\
\text { pembelajaran }\end{array}$ \\
\hline
\end{tabular}

\section{HASIL DAN PEMBAHASAN}

\section{A. Perlakuan Pembelajaran pada Kelas Eksperimen dan Kelas Kontrol}

a. Kelas Eksperimen

Pertemuan pertama pada kelas eksperimen dilakukan pada hari Senin tanggal 27 April 2019 yang berlangsung pukul 13.00 sampai 14.35 WIB dengan indikator menjelaskan siklus air berbantuan media komik. Pertemuan kedua pada hari Senin tanggal 3 Mei 2019 yang berlangsung pukul 13.00 sampai 14.35 WIB dengan indikator menjelaskan penyebab terjadinya siklus air berbantuan dengan media komik. Pertemuan ketiga pada hari Senin tanggal 10 Mei 2019 yang berlangsung pukul 13.00 sampai 14.35 dilakukan tes akhir dengan menyebar angket minat belajar. Untuk lebih 
detailnya perlakuan yang diberikan pada kelas eksperimen adalah:

1. Membentuk siswa menjadi enam kelompok. Dimana setiap kelompok terdiri dari lima sampai enam orang.

2. Membagikan media komik kepada setiap kelompok dalam bentuk hardcopy dalam kertas A4 yang telah digabungkan

3. Siswa berdiskusi dengan kelompok masing-masing untuk menyimpulkan isi cerita yang terkandung di dalam komik

4. Serta mencari istilah-istilah geografi yang ada di dalam komik.

5. Seorang siswa mewakili kelompoknya menyampaikan hasil analisis mereka terhadap cerita di dalam komik.

6. Memberikan penilaian berupa angket minat belajar siswa

Langkah selanjutnya setelah pengambilan data minat belajar uji prasyarat berupa uji normalitas dan uji homogenitas. Uji normalitas data dilakukan untuk mengetahui apakah data yang akan digunakan normal atau tidak. Sebab uji statistik baru bisa digunakan apabila data tersebut berdistribusi normal. Sebelum dilakukan uji normalitas, data terlebih dahulu disusun kedalam daftar distribusi frekuensi, kemudian menentukan rata-rata nilai $(x)$, simpangan $(\mathrm{S})$, dan Modus (Mo).

Selanjutnya dari hasil perolehan rata-rata Standar Deviasi (S) dan Modus (Mo) data tersebut di uji kenormalannya dengan rumus kemiringan kurva-Karl Pearson. Data dapat dikatakan berdistribusi normal apabila $\mathrm{Km}$ terletak di antara (-1) dan (1). Dari perhitungan kemiringan kurva menggunakan rumus Karl Pearson, diperoleh nilai 0,12 . Nilai 0,12 terletak diantara -1 dan 1 . Maka, data hasil tes pada kelas eksperimen berdistribusi normal.

Analisa yang digunakan untuk menguji kesamaan varians dalam penelitian ini, yakni dengan menggunakan uji Bartlett menggunakan tabel F dengan taraf nyata $\alpha=0,05$ dperoleh $\chi^{2}$ tabel $=3,84$ dan $\chi^{2}$ hitung $=3,06$ dan diketahui syarat homogenitas $=\chi^{2}{ }_{\text {hitung }}<\chi_{\text {tabel }}^{2}$, maka dapat ditulis $3,06<3,84$. Jadi dapat disimpulkan sampel berasal dari populasi yang sama atau homogen.

Berikut ini adalah beberapa contoh gambar komik yang digunakan pada kelas eksperimen yang bersumber dari Sholiha (2016):

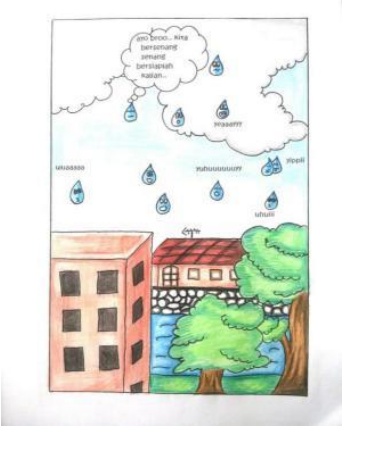

Gambar 1. Komik Siklus Hidrologi

\section{b. Kelas Kontrol}

Untuk kelas kontrol, pertemuan pertama pada hari Kamis tanggal 30 April 2019 yang berlangsung pukul 13.45 sampai 15:00 WIB dengan indikator menjelaskan indikator kualitas air secara fisik. Pertemuan kedua pada hari Kamis tanggal 6 Mei 2019 yang berlangsung pukul 13.45 sampai 15.00 WIB dengan indikator menjelaskan penyebab terjadinya siklus air. Pertemuan ketiga pada hari Kamis tanggal 20 Mei 2019 yang berlangsung pukul 13.45 sampai 15.00 WIB

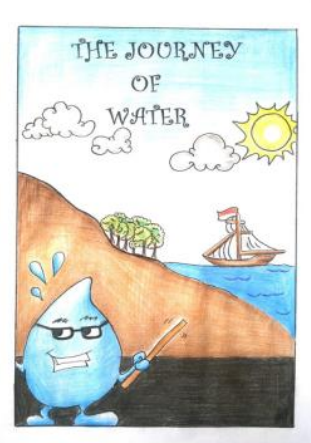
dilakukan penilaian dengan menyebar angket minat belajar. Sedangkan perlakuan/kegiatan pembelajaran sama 
dengan perlakukan pada kelas eksperimen, yang membedakan adalah pembelajaran pada kelas kontrol tidak menggunakan media komik. Pembelajaran geografi sepenuhnya bersumber dari buku.

Hasil uji coba prasyarat untuk normalitas berdasarkan perhitungan kemiringan kurva menggunakan rumus Karl Pearson, diperoleh nilai 0,04 . Nilai 0,04 terletak diantara -1 dan 1 . Maka, data hasil tes pada kelas eksperimen berdistribusi normal. Analisa yang digunakan untuk menguji kesamaan varians dalam penelitian ini, yakni dengan menggunakan uji Bartlett menggunakan tabel $\mathrm{F}$ dengan taraf nyata $\alpha=0,05$ dperoleh $\chi_{\text {tabel }}^{2}$ $=3,84$ dan $\chi^{2}$ hitung $=3,06$ dan diketahui syarat homogenitas $=\chi^{2}{ }_{\text {hitung }}<\chi^{2}$ tabel, maka dapat ditulis $3,06<3,84$. Jadi dapat disimpulkan sampel berasal dari populasi yang sama atau homogen.

\section{B. Hasil Analisis Data Minat Belajar}

Setelah disimpulkan bahwa data penelitian ini terbukti normal dan homogen melalui uji prasyarat, langkah yang selanjutnya adalah menguji hipotesis. Perbandingan nilai hasil analisis angket minat belajar antara kelas eksperimen dan kelas kontrol dapat dilihat pada tabel berikut.

Tabel 3. Data Minat Belajar Kelas Eksperimen dan Kelas Kontrol

\begin{tabular}{|l|l|l|l|l|}
\hline No & \multicolumn{1}{|c|}{ Kelas } & $\begin{array}{c}\text { Nilai } \\
\text { Tertinggi }\end{array}$ & $\begin{array}{c}\text { Nilai } \\
\text { Terendah }\end{array}$ & $\begin{array}{c}\text { Nilai } \\
\text { Rata- } \\
\text { rata }\end{array}$ \\
\hline 1 & Eksperimen & 135 & 90 & 117,7 \\
\hline 2 & Kontrol & 120 & 85 & 105,7 \\
\hline
\end{tabular}

Sumber : Pengolahan Data Primer 2019

Berdasarkan tabel di atas, diketahui minat belajar siswa kelas $\mathrm{X}$ IPS 1 sebagai kelas eksperimen yang menggunakan media komik sebagai media pembelajaran memiliki nilai tinggi dibandingkan minat belajar kelas X IPS 2 sebagai kelas kontrol yang tidak menggunkan media komik sebagai media pembelajaran di kelas. Hal ini terjadi karena pembelajaran menggunakan media komik, siswa menjadi lebih bersemangat dalam belajar. Beberapa alasan menurut pengamatan peneliti diantaranya adalah:

1. Siswa belum pernah menggunakan media komik sebelumnya, media yang dipakai biasanya adalah gambar

2. Sebagian besar siswa gemar membaca komik dalam bentuk cetak

3. Siswa sangat terkesan karena tidak menyangka sebelumnya bahwa ada komik yang berisi ilustrasi materi pembelajaran geografi yang bisa dijadikan sebagai media pembelajaran yang belum pernah mereka temukan sebelumnya

4. Dengan medai komik, materi pelajaran yang berkaitan dengan hidrofer yang terlihat susah dan membosankan, bisa menjadi materi yang menyenangkan dan tidak membosankan.

Jika dalam pembelajaran terdapat minat yang tinggi pada siswa, maka itu merupakan hal yang baik. Menurut Darmadi (2017) orang yang mempunyai keinginan atau senang terhadap sesuatu, ia akan memiliki usaha dan perjuangan yang lebih keras untuk memperoleh sesuatu yang disenanginya atau dengan kata lain jika seseorang menyukai atau berminat terhadap sesuatu, maka ia akan termotivasi untuk mendapatkan atau melakukan sesuatu tersebut.

Setelah dilakukan penghutungan hipotesis dengan terlebih dahulu menghitung angka $t_{\text {tabel }}$ dan $\mathrm{t}_{\text {hitung }}$ yang dihitung dengan rumus uji $\mathrm{t}$ secara manual maka ditemukan hasil nilai $t_{\text {hitung }}$ adalah 14.1 sedangkan nilai $t_{\text {tabel }}$ adalah 1.67 . Berdasarkan kriteria pengujian hipotesis apabila $t_{\text {hitung }}>t_{\text {tabel }}$ maka hipotesis diterima, karena dalam perhitungan uji t pada penelitian ini adalah nilai $t_{\text {hitung }}$ lebih besar daripada nilai $t_{\text {tabel }}$ atau 14,1 > 1,67 maka dapat dikatakan bahwa hipotesis $\mathrm{Ha}$ diterima. Sehingga hipotesis yang diajukan yang menyatakan bahwa penggunaan media komik dapat mempengaruhi minat belajar siswa kelas $\mathrm{X}$ di SMA Karya Ibu Palembang pada materi siklus hidrologi dapat diterima kebenarannya. Ini berarti hipotesis nol (Ho) yang berbunyi "tidak ada pengaruh signifikan media komik terhadap minat belajar geografi siswa" ditolak. 
Penelitian ini berhasil memberikan pengaruh yang signifikan terhadap minat belajar siswa, hal ini disebabkan karena siswa sangat tertarik dengan penggunaan media komik dalam pembelajaran. Karena sebelumnya guru di kelas sangat jarang dalam menggunakan media pembelajaran terutama media komik yang sama sekali belum pernah ada dalam pembelajaran, sehingga menimbulkan antusias dan keseriusan siswa untuk memperhatikan materi yang sedang dipelajari, sehingga menyebabkan siswa lebih mudah dalam memahami pelajaran serta meningkatkan minat belajar siswa.

Menurut Sudjana dan Rivai (dalam Jalinus, 2016) mengemukakan beberapa manfaat media dalam proses belajar siswa, yaitu: 1) membuat siswa menjadi termotivasi untuk dengan pembelajaran yang lebih menarik melalui media, 2) penyampaian bahan pembelajaran akan menjadi lebih jelas sehingga dapat dipahami siswa, 3) penggunaan metode mengajar akan lebih bervariasi, karena penggunaan media akan mencegah penggunaan metode pembelajaran konvensional, dan 4) akan lebih banyak aktivitas yang dilakukan siswa berkaitan dengan pembelajaran seperti mengamati, mendemonstrasikan, melakukan langsung, dan memerankan. Sementara fungsi media visual secara kognitif menurut Levied dan Lentz (dalam Arsyad, 2013 bahwa penyajian dalam bentuk visual atau gambar mempermudah mencapai tujuan-tujuan dalam memahami dan mengingat informasi atau materi yang terkandung dalam gambar.

\section{KESIMPULAN}

Berdasarkan hasil analisis data dan pembahasan mengenai pemanfaatan media komik terhadap minat belajar geografi siswa kelas $\mathrm{X}$ di SMA Karya Ibu Palembang dapat disimpulkan bahwa hasil analisis data rata-rata hasil tes minat belajar siswa kelas eksperimen sebesar 117,7 sedangkan kelas kontrol rata-rata hasil tes minat belajar siswa sebesar 105,7. Berdasarkan hasil uji$\mathrm{t}$ diperoleh $\mathrm{t}_{\text {hitung }}=14,1$ kemudian dibandingkan dengan $t_{\text {tabel }}=1,6732$ maka $t_{\text {hitung }}>t_{\text {tabel }}$ yaitu 14,1
> 1,6732 maka hipotesis yang menyatakan terdapat pengaruh media komik terhadap minat belajar geografi siswa kelas X di SMA Karya Ibu Palembang Tahun Ajaran 2018/2019 diterima (terima $\mathrm{Ha}$ ).

Sehingga penggunaan media visual komik direkomendasikan sebagai salah satu alternatif alat bantu penyampai materi ajar yang menyanangkan serta dapat meningkatkan aktivitas dan minat belajar siswa dalam pelajaran geografi khususnya materi hidrologi.

\section{DAFTAR PUSTAKA}

Sadiman, Arif S, dkk. (2014). Media Pendidikan : Pengertian, Pengembangan dan Pemanfaatannya. Depok: PT. Raja Grafindo Persada.

Arsyad, A. (2013). Media Pembelajaran. Jakarta: Rajagrafindo Persada.

Bintarto. (1988). Ruang Lingkup dan Konsep Geografi Sebagai Suatu Disiplin Keilmuwan. Makalah Lokakarya Pengembangan Konsep Geografi dalam Ajaran Sekolah. Yogyakarta: IKIP.

Darmadi. (2017). Pengembangan Model dan Metode Pembelajaran dalam Dinamika Belajar Siswa. Yogyakarta: Deepublish.

Jalinus, Nizwardi dan Ambiyar. (2016). Media dan Sumber Pembelajaran. Jakarta: Kencana.

Larasati, Siti. (2016). Penggunaan Media Komik Terhadap Minat, Motivasi dan Hasil Belajar Siswa pada Mata Pelajaran IPS Geografi Kelas VII SMP N 7 Metro Tahun Pelajaran 2015/2016. Skripsi. Universitas Lampung: Bandar Lampung.

Lestari, S., C, S. P., dan Yuniarti. (2009). Media Komik. Universitas Pendidikan Indonesia:. Media Grafis Media Komik.

Maryani, Enok. (2011). Pengembangan Program Pembelajaran IPS Untuk Peningkatan Keterampilan Sosial. Bandung: Alfabeta.

Oktavianto, Dwi Angga. (2019). Riset Pendidikan Geografi. Kalimantan Selatan: CV. Cipta Griya Pustaka.

McCloud, Scott. (2002). Understanding Comics. Jakarta: KPG. 
Sholiha, Arina. (2016). Komik Siklus Hidrologi. http://arinacan.blogspot.com/2016/. Dikutip pada April 2019.

Siyoto, Sandu dan Sodik, Ali. (2015). Dasar Metodologi Penelitian. Yogyakarta: Literasi Media Publishing.

Sugiyono. (2016). Metode Penelitian Kuantitatif, Kualitatif, $R \& D$. Bandung : IKAPI.

Sumiharsono, Rudy dan Hasanah, Hisbiyatul. (2017). Media Pembelajaran. Jember: CV. Pustaka Abadi. 